\title{
Subungual squamous cell carcinoma
}

\author{
Kai Yuen Wong, Daniel L H Ching, David Gateley
}

Department of Plastic and Reconstructive Surgery, St George's Healthcare NHS Trust, London, UK

\section{Correspondence to}

Kai Yuen Wong,

kaiyuen.wong@cantab.net

KYW and DLHC contributed equally.

Accepted 14 December 2014

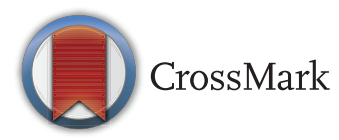

To cite: Wong KY,

Ching DLH, Gateley D. BM Case Rep Published online: [please include Day Month Year] doi:10.1136/bcr-2014207565

\section{SUMMARY}

Subungual squamous cell carcinoma (SCC) is rare. We present a case of subungual SCC with invasion into the underlying bone and review the literature.

\section{BACKGROUND}

Subungual squamous cell carcinoma (SCC) is rare and often presents with non-specific features that can mimic a range of other pathological conditions, leading to misdiagnosis and delayed treatment.

\section{CASE PRESENTATION}

A 52-year-old man presented to the emergency department with a 6-week history of increasing pain at the tip of his left non-dominant thumb. The patient denied any trauma to the digit. On examination, there were no signs of infection, inflammation or skin changes. He could move the thumb normally but had mild discomfort at its tip on palpation. The patient was subsequently discharged with analgaesia.

A month later, the patient presented to the emergency department with the same persistent symptoms. Apart from mild swelling of his left thumb tip there were no other abnormalities.

\section{INVESTIGATIONS}

An X-ray of the thumb showed a lucency of the distal phalanx (figure 1) and the patient was

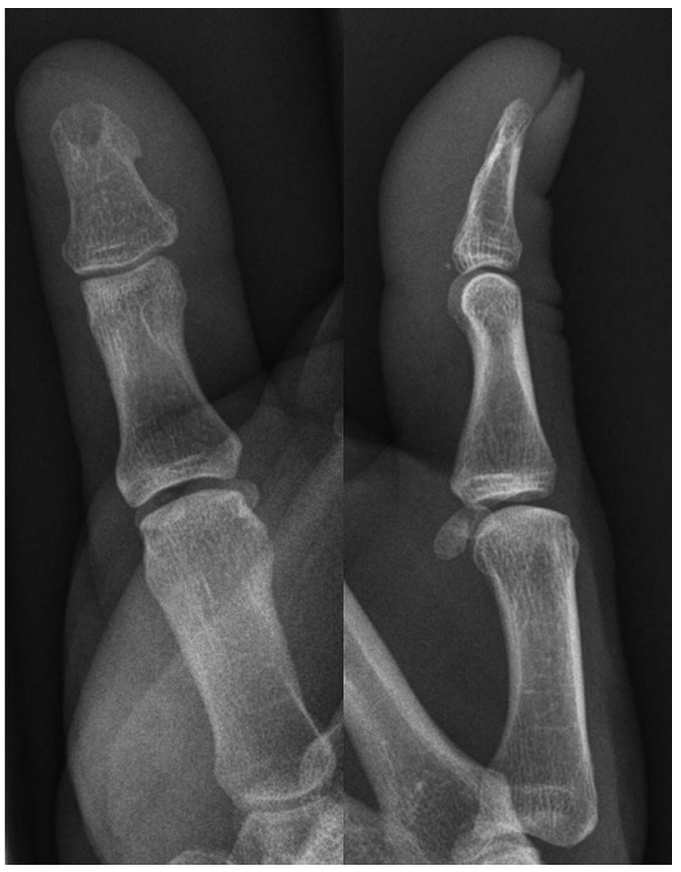

Figure 1 Posteroanterior and lateral view X-rays of the left thumb showing well-defined lucency at the tip of distal phalanx. started on intravenous antibiotics for suspected osteomyelitis.

\section{TREATMENT}

After review by the plastic surgery team, given the atypical presentation, an excisional biopsy was arranged to rule out a glomus tumour. Although dyskeratotic cells were present on histology, given the age of our patient and strong p53 staining in the majority of basal cells, ${ }^{1}$ the favoured diagnosis was a well-differentiated subungual SCC (figure 2). Subsequent skin cancer multidisciplinary team discussion recommended amputation through the interphalangeal joint.

\section{OUTCOME AND FOLLOW-UP}

Twelve months postoperatively, the patient is using his non-dominant hand for normal daily activities and has returned to work.

\section{DISCUSSION}

Subungual SCCs affect men more than women and usually present in the fifth to seventh decade of life. Commonly cited risk factors include trauma, radiation, chronic paronychia, human papillomavirus infection and dyskeratosis congenita. ${ }^{2}{ }^{3}$ They often present with non-specific features that can mimic other conditions. Average diagnosis time has been shown to be as long as 6 years, with one study reporting a 40 -year delay. ${ }^{2}{ }^{4}$ Other differential diagnoses for an erosive lesion of the distal phalanx include glomus tumour, giant cell tendon sheath tumour, subungual keratoacanthoma and mucous cyst. ${ }^{5}$ Most reported cases are associated with subungual hyperkeratosis, onycholysis, oozing

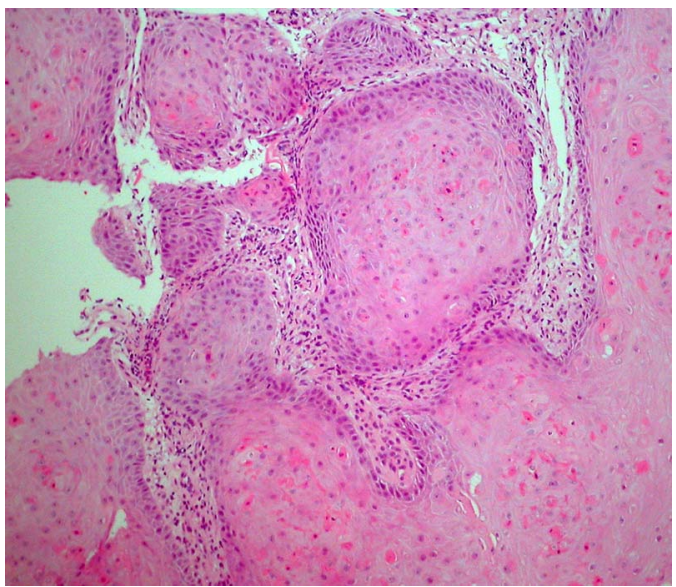

Figure 2 Histology of the left thumb distal phalanx bone biopsy showing fragments of a well-differentiated squamous cell carcinoma. 


\section{Rare disease}

and nail plate destruction, ${ }^{2}$ none of which were present in this case. Pain is a fairly non-specific symptom and subungual keratoacanthomas may have a similar presentation to subungual SCCs. The former tend to present earlier in life. ${ }^{5}$ It is important to distinguish between the two, as the treatment for subungual keratocanthomas is generally conservative.

Management of subungual SCCs is directly related to the extent of local invasion, hence early diagnosis is essential. Various treatments have been proposed including Mohs micrographic surgery, wide local excision with skin graft or local flap, and amputation of the digit. Given the rarity of the condition, there is no consensus on the optimal treatment. Mohs surgery has been proposed as the treatment of choice; in a series of

\section{Learning points}

- Subungual squamous cell carcinoma is rare. It often presents with non-specific features and can therefore mimic a range of other pathological conditions.

- Although uncommon, it is important to consider malignancy in the presence of persistent symptoms that are unresponsive to treatment to prevent delayed diagnosis and progression of disease.

- An excisional biopsy is required for diagnosis and to guide subsequent management.
14 patients there was a reported clearance rate of $78 \%$ without compromising surrounding tissue. ${ }^{7}$

Although these tumours are uncommon, it is important to consider malignancy in the presence of persistent symptoms that are unresponsive to treatment to prevent delayed diagnosis and progression of disease. Ultimately, an excisional biopsy is required for diagnosis and to guide subsequent management.

Acknowledgements The author would like to thank Dr Heong Chong, Consultant Histopathologist.

Competing interests None.

Patient consent Obtained.

Provenance and peer review Not commissioned; externally peer reviewed.

\section{REFERENCES}

1 Connolly M, Narayan S, Oxley J, et al. Immunohistochemical staining for the differentiation of subungual keratoacanthoma from subungual squamous cell carcinoma. Clin Exp Dermatol 2008;33:625-8.

2 Lecerf $P$, Richert $B$, Theunis $A$, et al. A retrospective study of squamous cell carcinoma of the nail unit diagnosed in a Belgian general hospital over a 15-year period. J Am Acad Dermatol 2013;69:253-61.

3 Patel PP, Hoppe IC, Robert Bell W, et al. Perils of diagnosis and detection of subungual squamous cell carcinoma. Ann Dermatol 2011;23:285-7.

4 Hale LR, Dawber RPR. Subungual squamous cell carcinoma presenting with minimal nail changes: a factor in delayed diagnosis? Australas J Dermatol 1998;39:86-8.

5 Bui-Mansfield LT, Pulcini JP, Rose S. Subungual squamous cell carcinoma of the finger. AJR Am J Roentgenol 2005;185:174-5.

6 Levy DW, Bonakdarpour A, Putong PB, et al. Subungual keratoacanthoma. Skeletal Radiol 1985;13:287-90.

7 Young LC, Tuxen AJ, Goodman G. Mohs' micrographic surgery as treatment for squamous dysplasia of the nail unit. Australas J Dermatol 2012;53:123-7.

Copyright 2015 BMJ Publishing Group. All rights reserved. For permission to reuse any of this content visit

http://group.bmj.com/group/rights-licensing/permissions.

BMJ Case Report Fellows may re-use this article for personal use and teaching without any further permission.

Become a Fellow of BMJ Case Reports today and you can:

- Submit as many cases as you like

- Enjoy fast sympathetic peer review and rapid publication of accepted articles

- Access all the published articles

- Re-use any of the published material for personal use and teaching without further permission

For information on Institutional Fellowships contact consortiasales@bmjgroup.com

Visit casereports.bmj.com for more articles like this and to become a Fellow 